Article

\title{
Clinical Perspective on Internet of Things Applications for Care of the Elderly
}

\author{
Soe Ye Yint Tun ${ }^{1} \mathbb{D}$, Samaneh Madanian ${ }^{2, * \mathbb{B}}$ and Dave Parry ${ }^{2}$ \\ 1 Department of Public Health, Ministry of Health and Sports (MoHS), Naypyitaw 15015, Myanmar; \\ syytun@gmail.com \\ 2 School of Engineering, Computer and Mathematical Sciences, Auckland University of Technology, \\ Auckland 1010, New Zealand; dave.parry@aut.ac.nz \\ * Correspondence: sam.madanian@aut.ac.nz
}

Received: 16 October 2020; Accepted: 12 November 2020; Published: 16 November 2020

\begin{abstract}
The elderly population is increasing globally, putting more pressure on aged care and public health systems. To address this issue and help increase the independence of older people, different digital technologies, including the Internet of things (IoT), can play an important role. Although there has been an increase in the number of studies in this field, most of them concentrate on IoT applications in elderly care from a technology perspective, with very little contribution from the clinical side. Therefore, this paper aims to investigate and identify the available IoT applications and their clinical utility for common diseases in elderly people. The results of this study could be useful for information technology professionals in developing and understanding the clinical requirements for IoT applications in healthcare for older people. Clinicians will also be informed about the clinical possibilities of using IoT devices in this area. Based on our findings, future research should focus on enhancing the clinical utility of current IoT applications in different settings and on developing new applications to support practitioners and older people.
\end{abstract}

Keywords: Internet of things; IoT; elderly care; elderly; clinical perspective

\section{Introduction}

Improvements in clinical science and technology enhancement have increased the average life expectancy in most countries. Paradoxically, this has resulted in increasing the number of people living with chronic diseases associated with aging. This leads to increasing costs and pressure on healthcare systems [1,2]. In addition, the elderly population is growing at a faster rate than the younger age groups around most of the world. Based on recent statistics, in 2019, the number of people aged 65 years and older was 703 million, which is expected to reach 1.5 billion in 2050, doubling the current elderly population [3]. The number of elderly people aged 65 years and older in New Zealand will also approximately double from 711,200 in 2016 to between 1.3 and 1.5 million in 2046 [4]. This increase, in turn, puts greater than before pressure on old age healthcare systems and support systems and increases the number of retired people that each working age person has to support [3,5].

In response, different strategies can be defined for healthcare providers to reduce their operational costs while improving patient outcomes in this group. The adoption of new technology is one of the enablers to achieve this goal [6]. Technology can play an important role in healthcare through process automation and monitoring patients and their health statuses anytime and anywhere. Technology-enabled strategies, also known as digital transformation, allow healthcare providers to give routine care in patients' homes rather than in hospitals, which can produce savings and decrease the pressure on healthcare systems [7]. 
Technology can also support services for older adults that allow them to lead independent lifestyles at home for longer while receiving quality physical and clinical services [8]. One of these technologies is the Internet of things (IoT). IoT applications in healthcare have attracted a great deal of interest recently, and this continues to increase. The IoT is a framework that allows various sensors, devices, and systems to communicate and connect. The development of the IoT, wearable sensors, and smartphone technologies has also changed ways of collecting and analyzing data. IoT integration with other technologies, such as artificial intelligence (AI) and big data analytics, can be used for different purposes, including healthcare monitoring, diagnosis, and rehabilitation [9].

The IoT may have a potential impact in the areas of remote healthcare monitoring, continuous monitoring of chronic diseases, fitness, and wellness monitoring [10,11]. As the IoT collects data automatically and precisely, it could have an exponential impact on the organization of healthcare systems and ways of providing and delivering healthcare services, particularly for older people. The IoT could potentially speed up the process of diagnosis [12], improve care quality, lower the costs of hospitalizations [13], and enhance the quality of life and users' experiences [11]. It may also reduce the frequency of manual examinations for certain clinical parameters, as well as the frequency of data entry into the electronic health record (EHR), which in turn reduces the workload on clinicians. One of the greatest advantages of using the IoT for elderly care is that it allows older people to continue living their independent lives at home while their health statuses are being monitored, and they can obtain healthcare services remotely $[14,15]$.

IoT devices allow the continuous monitoring of patients in their residences or anywhere with an Internet connection, improving the engagement between healthcare providers and patients. Most importantly, a huge collection of longitudinal data from those IoT devices can provide new clinical insights after analysis by various methods [16]. These data could also help to develop more accurate clinical guidelines, which can be used to build automated clinical IoT devices, such as the artificial pancreas [17]. However, IoT devices, in order to be deployed in clinical settings and get physician endorsement, need to be evaluated and approved by regulatory bodies. In this regard, besides the focus on the technological aspect, considering the clinical requirements of IoT applications in healthcare is of prime importance.

In this paper, the background of the research is discussed in Section 2. The research methodology is explained in Section 3, followed by presenting the research results and discussion in Section 4. The paper is concluded in Section 5.

\section{Research Background}

A wide variety of studies have been carried out on improving elderly healthcare using different types of IoT devices, such as wearable devices and monitoring technologies for the elderly, reviewed in [14,15], based on increasing interest in approaches such as personal alarms, fall detection systems, and activity monitoring. The IoT has also been proposed for older adults in the areas of tracking indoor locations, recognizing physical activities, and monitoring vital signs in real-time [18]. Activity monitoring systems based on wearable sensors for older adults are reviewed in [19], and their challenges and problems have been identified. A very recent research study, conducted in [7], classified all the applications of the IoT for elderly care into 11, areas including aged care monitoring, human activity recognition, clinical applications, and emergency conditions. Despite the recent increase in interest in this area, most of the research studies are from a technological perspective [7]. There has been some limited research conducted in IoT user-centered areas, such as in [20,21]. However, very few studies have explored the applications of the IoT in elderly health care from the clinical view [7].

However, in many cases, IoT developments are more focused on the availability of technology than on clinical requirements, but later become adopted for clinical uses. For example, wearable and IoT devices are becoming more and more popular, and have started transforming from wellness devices into clinical devices [22]. Patients can visit physicians with a huge amount of data from their wearable healthcare devices that might help the physicians to make more informed and evidence-based 
decisions. However, the data collected by different IoT devices are not equally valuable clinically, and this may make it difficult for clinicians to use information from these sources [23]. In addition, it is often not clear to clinicians how accurate the information from wearable devices is, as they are not evaluated by bodies such as the U.S. Food and Drug Administration (FDA) or other regulatory bodies for clinical use. Indeed, most of the IoT and wearable devices available in the market have not been approved by the FDA for application in clinical settings [23], and the FDA has specifically avoided taking responsibility for regulating low-risk healthcare IoT devices aimed at general wellness [22].

The lack of a clear understanding between wellness and clinical IoT devices has confused clinicians, as well as the patients. Wellness devices are becoming more and more prevalent tools for healthcare monitoring and have invaded the boundaries of traditional medical devices and healthcare methods [24]. On one hand, the increase in the availability and adoption of personal wellness devices could bring about the advancement of health consumer behavior, where patients are involved more deeply in taking care of their healthcare [24]. On the other hand, the use of clinically unvalidated IoT and wearable devices could produce a large amount of clinically unreliable data, resulting in the inefficient usage of such devices.

In order to help overcome these issues, the objective of this paper is to identify any potential areas where the IoT can support practitioners and evaluate the current IoT applications and their limitations that may hinder their usage in a clinical setting. This study seeks to identify the clinically important data required for elderly healthcare, investigate the availability of IoT or wearable technology for those data, and evaluate the accuracy of the available IoT devices applicable in the clinical setting. The major contribution of this research is the assessment of IoT and wearable devices for elderly healthcare, in terms of clinical usage.

\section{Materials and Methods}

To conduct this research, a cross-case analysis was used. Cross-case analysis is a qualitative research method that enables the units of analyses in case studies, such as events, activities, and processes, to be compared and gain insights based on commonalities and differences. The cross-case analysis method can also be used for progressive tabling to form a chain of reasoning from findings and interpretations of existing studies and relevant theories [25]. Although cross-case analysis is often used as a broad umbrella term to represent the analysis of two or more case studies to synthesize outcomes, it can also be used as a specific method to analyze and organize the data from the cases into tables and graphs. Some advantages of the cross-case analysis method are as follows: (1) the case content is prepared in an easily accessible form; (2) cases are categorized and displayed in a way that facilitates comparison; (3) either cases or variables can be compared, depending on the researcher's goal; and (4) findings of the comparison can be shared $[25,26]$.

The overall research approach in this study was undertaken into two phases (Figure 1):

- Phase 1: Identification of clinically required data for common diseases in the elderly population.

- Phase 2: Cross-case analysis of the data types identified in Phase 1 with the available IoT applications.

The data analysis was conducted in two phases, mapped with the overall research approach. In the following sub-sections, the details of these phases are provided. The results of each phase and their discussions are presented in Section 4. 


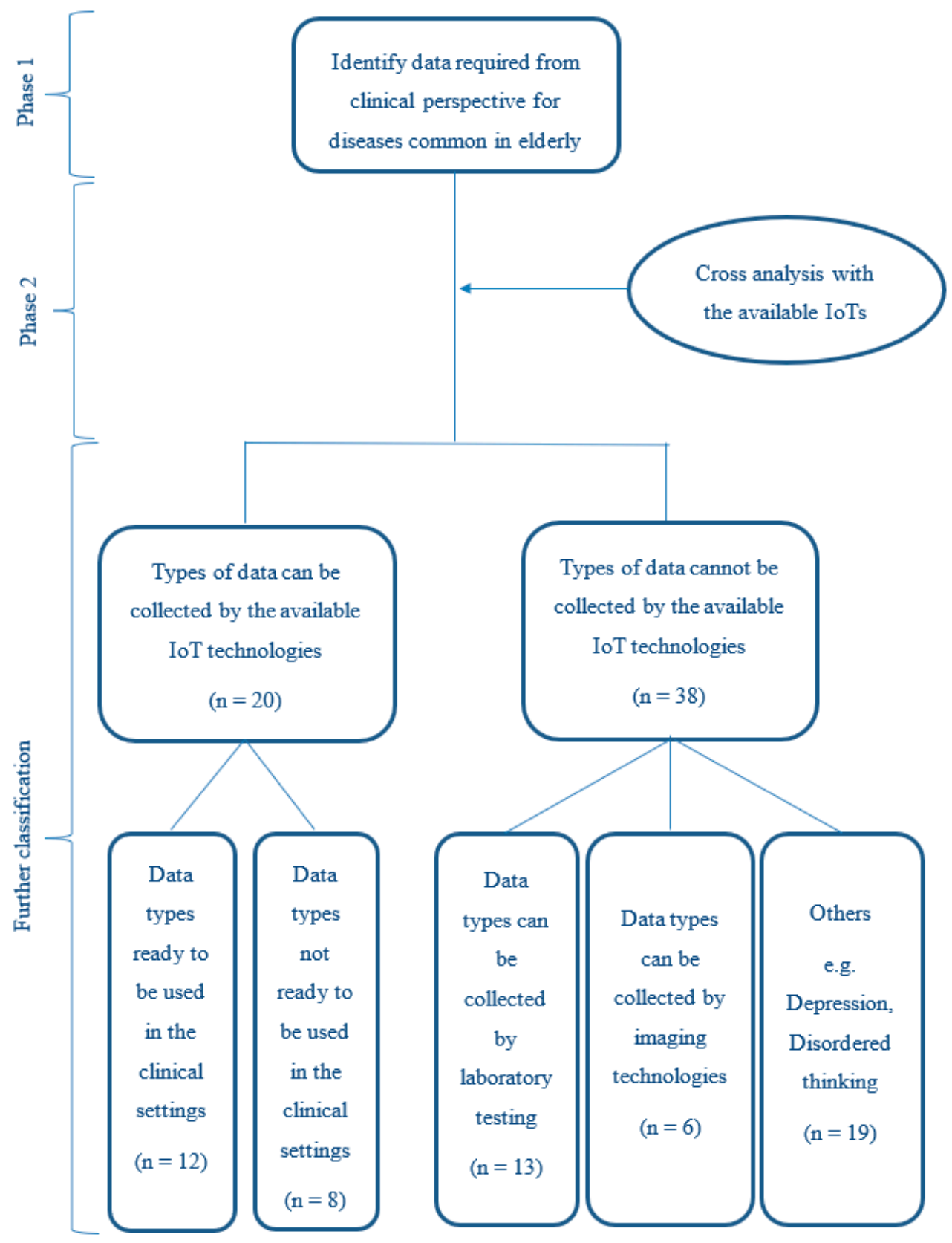

Figure 1. The overall research approach.

\subsection{Phase 1: Identification of Clinically Required Data for Common Diseases in the Elderly Population}

During this phase, some of the common diseases in the elderly population were investigated. These diseases were chosen based on the published articles in this area [7,27-29]. Based on these research studies, common diseases and ailments in the elderly include coronary heart disease, strokes, diabetes mellitus, hypertension, chronic renal disease, delirium, Parkinson's disease, and falling.

To identify the required data and their types for each disease, two major medical training sources were used as references: Wilkinson et al. [30] and Ralston, Penman, Strachan and Hobson [27]. In addition, one of the researchers is a medical doctor practicing in Myanmar and familiar with the clinical data requirements to examine patients with such diseases. 
All of the identified diseases were investigated from the clinical perspective through six stages of the clinical care process: screening, diagnosis, treatment, monitoring, rehabilitation, and follow-ups [31-33]. These stages of the clinical care process are well known and can be applied to the clinical management of almost all diseases.

With the progress of this research, some overlappings were identified between the screening and diagnosis stages in regard to the required data and data types. Therefore, we slightly modified the clinical procedure stages in this research and combined the screening and diagnosis stages, presenting them as one group. In addition, the monitoring of treatment and rehabilitation stages were combined and discussed separately in Section 4.6, as the data required for the monitoring of treatment and rehabilitation were almost identical for the identified diseases in this research. A table that presents the diseases and the required clinical data in each stage of the clinical procedure is available in Table A1.

\subsection{Phase 2: Cross-Case Analysis of Data Types Identified in Phase 1 with the Available IoT Applications}

In the second phase, we referred to the hierarchy of IoT applications for elderly healthcare (Figure A1), which was introduced and discussed in [7]. Based on this research, IoT applications for older adults were classified into the following categories: aged care monitoring, chronic patient healthcare monitoring, human activity recognition, clinical applications, emergency conditions, mental health, movement disorders, rehabilitation, preventive measures, accessibility for caregivers, and accessibility to healthcare services (self-management).

By referring to these categories, we identified the IoT applications, devices, and types of collected data. The objective was to discover the types of data that could be collected with the current IoT devices in elderly care.

In the next step, a cross-case analysis was undertaken between the required clinical data from Phase 1 (Table A1) and the hierarchy of available IoT applications for elderly healthcare (Figure A1). The final objective in this phase was to identify which types of clinically required data for the targeted common elderly diseases could be collected using IoT applications and devices and whether they were acceptable from the clinical perspective. The full list of the results of this phase is shown in Table A2.

\section{Results and Discussions}

In total, 20 types of data could be collected by available IoT devices and applications. These data, based on their accuracy from the clinical perspective and application, can be categorized into accurate and ready to use or not accurate enough to be used for clinical applications. In this context, data accuracy means that IoT devices have been approved by the FDA or other regulatory bodies for usage in a clinical environment, or these devices have reached a level where physicians can refer to the collected data with confidence about their accuracy and probably include them in their clinical interventions and decision-making.

In this stage, all 20 types of data that could be collected by the available IoT devices were investigated one by one to identify whether the collected data was accurate or approved by regulatory bodies such as the FDA. Among these 20 data types, 12 could be measured accurately and, in some cases, clinicians are already using them for monitoring certain diseases in patients. These types of devices are built specifically for health monitoring with the involvement of clinical input from physicians, such as smart continuous glucose-monitoring devices [23] and blood glucose sensors, or glucometers, for the monitoring of diabetes mellitus [34]. These devices are strictly regulated with clinical validation and aimed to be used in a clinical environment [15].

On the other hand, eight types of data were not accurate enough to be used in clinical procedures. These data required further development and validation to be applied for clinical usage with confidence. The list of these two categories of data is presented in Table 1. 
Table 1. List of data types that can be collected by the available Internet of things (IoT) devices.

\begin{tabular}{cc}
\hline Ready to be Used in the Clinical Setting & Not Ready to be Used in the Clinical Setting \\
\hline Pulse Rate [35,36] & ECG [37] \\
Blood Pressure [35] & REM Sleep Disorders [38] \\
Temperature [39,40] & Reversal of Sleep-Awake Cycle [38] \\
Oxygen Saturation [35,36] & Urine Output [41,42] \\
Blood Glucose [34] & Fluid Intake and Output [41,42] \\
Body Weight and Height [43] & Postural Instability [44,45] \\
Early Detection of Falls [46] & EEG [47] \\
Tremor [48] & Urinary Retention and Incontinence [7] \\
Creatinine for Glomerular Filtration Rate [49] & \\
Balance [50] & \\
Gait [51,52] & \\
Lipid Profile [53]
\end{tabular}

Despite significant growth and enhancement in IoT devices and sensors and their applications in healthcare, there are still several types of data that currently cannot be collected using IoT devices. In the context of this work, there are 38 data types that cannot be collected using IoT devices (Table 2). These data were classified into three separate categories, based on the type of interventions required to collect them. They were (1) laboratory test, (2) imaging technology, and (3) others.

Table 2. List of data types that cannot be collected by the available IoT devices.

\begin{tabular}{ccc}
\hline Laboratory Test & Imaging Technology & Others \\
\hline Cardiac Enzymes & CT/CT Angiogram & Rigidity/Increased Tone \\
Urea and Electrolytes & MRI/MR Angiogram & Bradykinesia/Hypokinesia \\
HBA1C & X-rays & Poor Executive Functioning \\
Full Blood Count & Echocardiogram & Depression \\
Hemoglobin & Ultrasound & Dementia \\
Liver Function Test & Cataract & Psychosis \\
Arterial Blood Gas & & Disordered Thinking \\
Septic Screen & & Euphoric, Fearful, Depressed, or \\
Lumber Punctured & Angry \\
Thyroid Function Test & Language Impaired \\
Urine Albumin & & Illusion/Delusion/Hallucinations \\
ESR & & Inattention \\
Malaria & Unaware/Disorientated \\
& Memory Deficits \\
& & Vision or Cognitive Function \\
& Conscious Level \\
& Aspiration \\
& & Constipation and Bowel Incontinence \\
& Freezing while Walking \\
& Posture (Proper Positioning) \\
\hline
\end{tabular}

To address the identified research gaps, a critical analysis of each disease, and clinically required data for the management of such diseases, was performed to provide insights on clinical perspectives regarding IoT applications. In the following sub-sections, the discussion on the results of the cross-case analysis is provided for each common disease in the elderly population.

\subsection{Cardiovascular Diseases (CVDs)}

Cardiovascular diseases (CVDs) are the number one cause of death in the world, with an estimated 17.9 million deaths every year, and two-thirds of these deaths are among those over 70 years old [54]. CVDs include diseases caused by disorders of the heart and blood vessels, including coronary heart disease, cerebrovascular disease (stroke), rheumatic heart disease, and other disorders. Heart attacks 
and strokes are responsible for $85 \%$ of the deaths caused by CVDs [54]. The risk of having a CVD is associated with the patient having CVD risk factors, such as diabetes mellitus, hypertension, high cholesterol, tobacco usage, obesity, physical inactivity, an unhealthy diet, and old age [27]. Therefore, it is important to keep monitoring the vital signs, blood glucose, and blood cholesterol of the elderly, especially for those who have any of the CVD risk factors.

Various IoT devices and sensors are available for monitoring the parameters mentioned in the previous section. Long-term continuous monitoring of the clinical data can provide deeper insights into the understanding of these diseases, and algorithms can be developed to predict and prevent possible risk factors. The types of data related to CVDs are discussed in the following sub-sections.

\subsubsection{Vital Signs}

Vital signs are important parameters in clinical settings for the diagnosis and monitoring of CVDs in elderly patients [55]. Vital signs include the pulse rate, blood pressure, body temperature, and respiratory rate. The pulse rate is the number of palpable pulses on the arteries caused by the pumping of blood from heart contractions within one minute, and it is the same as the heart rate [56]. Several IoT and wearable devices are available for detecting the pulse rate, although most of them are registered as wellness devices and not aimed for usage in a clinical environment.

FDA-approved IoT and wearable devices are available on the market for measuring patients' vital signs, but most of them can only measure one, two, or three of the four vital signs, and this might be a drawback for their application in clinical practice. For example, the MightSat Rx finger pulse oximeter [57] can measure both the respiratory rate and oxygen saturation from photoplethysmogram (RRp), and it has been approved by the FDA [36]. This device can be connected to smartphones and even be integrated into Apple's Health app [57]. However, it costs around 300 USD [58], more expensive than an average pulse oximeter. The Biobeat smartwatch is also approved by the FDA [59] and can measure blood pressure, respiratory rate, skin temperature, blood oxygenation, and pulse rate in both clinical and outpatient settings. The Biobeat smartwatch and patch have the same ability to measure clinical parameters, and only one device needs to be used at a time [35]. The patch can be attached anywhere on the upper torso. Currently, the Biobeat smartwatch costs around 1500 USD, and the patch costs 100 USD, but the prices are expected to reduce with mass production [60].

Currently, the devices that can measure all the vital signs are used mainly in operating rooms and intensive care units (ICUs) due to their high costs. If low-cost IoT devices are available and can be used to measure the vital signs of all patients in a hospital, the workload of health care professionals could be reduced greatly, since it would save time for performing the assessment of the vital signs as well as filling in medical records. IoT devices also allow the measurement to be done more frequently when needed without increasing visits to patients' bedsides. Therefore, having an IoT device that can measure all four vital signs accurately at the same time would be very useful for clinicians in providing constant and accurate data. These devices can also reduce the time taken for patient examination in healthcare settings. The recommended guideline for the measurement of vital signs is switching from traditional measurement devices to using electronic devices with sensors. According to the American Heart Association [61], the use of oscillometric devices which have pressure sensors inside the blood pressure cuff can not only reduce human errors, but also lower the risk to the environment in contrast to mercury sphygmomanometers. Similarly, digital electronic thermometers are becoming more popular due to their user friendliness and the prohibitions on the use of mercury thermometers [40]. Moreover, non-contact infrared thermometers (NCITs) that use an infrared sensor to capture heat from the forehead without touching it are becoming very useful in measuring temperature to reduce the risk of cross-contamination and the spread of diseases [39]. 


\subsubsection{Pulse Rhythms}

The pulse rate can be measured by most of the smartwatches and smartphones from their LED sensors. These devices also claim to deliver accurate measurements and are cheap [62]. The pulse sensors use an optical LED light shined into the blood vessel, and then the LED light sensor measures the reflected light from the blood. The amounts of reflection are different for the varying volumes of blood pulses, which can be interpreted as the pulse rate [63].

However, from the clinical perspective, the pulse rate alone is not enough. Other parameters such as the pulse rhythm and pulse volume are also essential. When a clinician examines a patient's pulse, parameters such as the rate, rhythm, character, and volume of the pulse are determined. For example, the interpretation of a normal healthy person's pulse examination would be as follows: the pulse rate is 72 beats per minute, regular rhythm, moderate volume with no special character. A difference in each parameter could point toward different types of diseases [30]. Therefore, IoT devices aimed to be applicable in the clinical environment should focus to include such parameters of pulse examination to increase the value and usage of those IoT devices.

\subsubsection{Coronary Heart Disease}

Coronary heart disease is the disease of the blood vessels supplying the heart muscle (partial or complete blockage of one or all of the coronary blood vessels), and it is one of the major causes of death among CVDs [54]. Diagnosis of coronary heart disease is clinically done by presenting signs and symptoms of the patient and is confirmed using electrocardiogram (ECG), with or without cardiac enzymes, depending on the availability and lapsed time [30]. Some other data are also used by clinicians in different clinical setting procedures (Table 3).

An ideal ECG used in the clinical environment is the 12-lead ECG, where the electronic signals from the heart are captured through 12 lead connected to specific locations on the body surface [30]. There are smartwatches available in the market today which measure using an ECG. However, these smartwatches use only single-lead ECG measurements. The Kardia Band (KB) [64], Apple Watch (Series 4-6) [65], and Verily's study watch [66] are smartwatches with single-lead ECGs approved by the FDA for the detection of atrial fibrillation (AF). Since AF is only one of many heart diseases that can be detected using an ECG in a clinical environment, the current IoT devices still have a long way to go to allow comprehensive measurement of clinically important ECG parameters. The latest product available in the market approved by the FDA is Kardia Mobile 6L [67], which is the first personal six-lead ECG [37]. According to [68], this device has demonstrated clinical equivalence measurement to the 6 limb leads of a standard 12-lead ECG and can provide numerous additional detections of ECG signals over the single-lead ECG. It costs around 150 USD [69], which is well within the price range of an average standard ECG [70]. The product was released in August 2019, so it has not yet been fully assessed in practice, though it is a step closer to having clinically accurate and reliable IoT-based ECG devices.

Table 3. Required data and IoT availability of coronary heart disease.

\begin{tabular}{cccc}
\hline IoT for Data Collection & Screening and Diagnosis & Monitoring & Follow Up \\
\hline \multirow{4}{*}{ Yes } & ECG [37] & ECG (Continuous) [37] & ECG [37] \\
& Blood Pressure [35] & Blood Pressure [35] & Blood Pressure [35] \\
& Pulse Rate [35,36] & Pulse Rate [35,36] & Pulse Rate [35,36] \\
& Temperature [39] & Temperature [39] & Oxygen Saturation [35,36] \\
& Oxygen Saturation [35,36] & Oxygen Saturation [35,36] & Blood Glucose [34] \\
& Blood Glucose [34] & Blood Glucose [34] & Lipid Profile [53] \\
& Lipid Profile [53] & Lipid Profile [53] & \\
\hline Pulse Rhythms & Pulse Rhythms & Pulse Rhythms \\
& Cardiac Enzymes & Cardiac Enzymes & Chest X-ray \\
Chest X-ray & Chest X-ray & Echocardiogram \\
& Echocardiogram & Echocardiogram & Urea and Electrolytes \\
\hline
\end{tabular}


Cardiac enzymes are released into the bloodstream of the patient when there is damage to the heart muscles (caused by a lack of blood supply in this case). Troponins I and $\mathrm{T}$ are the most sensitive and specific cardiac enzymes that are released when there is damage to the heart muscles. Troponins can be used to support the confirmation of diagnosis for acute coronary syndrome, where early diagnosis can help the survival of the patient $[27,30]$. However, there is no on-site testing device or method available for measuring troponin levels. The development of such a device could help clinicians to speed up the diagnosis process and save patients' lives.

\subsubsection{Stroke}

A stroke is the most common cause of severe physical disability in the elderly population, caused by brain damage due to ischemia (lack of blood supply) or a hemorrhage (bleeding) [27]. A stroke can be suspected by symptoms such as facial asymmetry, arm or leg weakness, and speech difficulty [30]. However, distinguishing between an ischemic stroke and a hemorrhagic stroke can only be done by imaging the brain with computed tomography (CT) or magnetic resonance imaging (MRI). It is important to confirm whether it is an ischemic or hemorrhagic stroke before giving definitive treatment, because treatment plans for the two of them are opposite in nature [27]. A CT or MRI needs to be done within $1 \mathrm{~h}$ of the onset of symptoms to exclude a hemorrhage when thrombolysis treatment is considered [30]. There are portable CT and MRI scanners available for usage which are reliable and feasible [71]. However, the ability to reach CT and MRI scanners in rural areas in developing countries is still limited.

To diagnose and treat strokes, different data are required, some of which can be collected using IoT devices (Table 4). However, as CT scans and MRIs are the main sources for physicians, at this stage, no sensor or IoT device or application is developed to help the physician in the early diagnosis of strokes.

Table 4. Required data and IoT availability for strokes.

\begin{tabular}{|c|c|c|c|}
\hline IoT for Data Collection & Screening and Diagnosis & Monitoring & Follow Up \\
\hline Yes & $\begin{array}{c}\text { ECG [37] } \\
\text { Blood Pressure [35] } \\
\text { Pulse Rate [35,36] } \\
\text { Temperature [39] } \\
\text { Oxygen Saturation [35,36] } \\
\text { Blood Glucose [34] } \\
\text { Lipid Profile [53] }\end{array}$ & $\begin{array}{c}\text { ECG (Continuous) [37] } \\
\text { Blood Pressure [35] } \\
\text { Pulse Rate [35,36] } \\
\text { Temperature [39] } \\
\text { Oxygen Saturation }[35,36] \\
\text { Gait }[51,52]\end{array}$ & $\begin{array}{c}\text { ECG [37] } \\
\text { Blood Pressure [35] } \\
\text { Pulse Rate [35,36] } \\
\text { Oxygen Saturation [35,36] } \\
\text { Pressure Ulcers [7] } \\
\text { Gait [51,52] }\end{array}$ \\
\hline No & $\begin{array}{l}\text { CT/CT Angiogram } \\
\text { MRI/MR Angiogram } \\
\text { Echocardiogram } \\
\text { Full Blood Count } \\
\text { ESR } \\
\text { Pulse Rhythms }\end{array}$ & $\begin{array}{c}\text { Conscious Level } \\
\text { Pulse Rhythms } \\
\text { Aspiration } \\
\text { Urinary Retention and } \\
\text { Incontinence } \\
\text { Constipation and Bowel } \\
\text { Incontinence } \\
\text { Posture }\end{array}$ & $\begin{array}{c}\text { Conscious Level } \\
\text { Pulse Rhythms } \\
\text { Aspiration } \\
\text { Urinary Retention and } \\
\text { Incontinence } \\
\text { Constipation and Bowel } \\
\text { Incontinence } \\
\text { Posture (Proper } \\
\text { Positioning) }\end{array}$ \\
\hline
\end{tabular}

\subsubsection{Dyslipidemia}

Dyslipidemia is a condition in which there is an elevation in plasma cholesterol or triglycerides (TGs) or a reduction in high-density lipoprotein (HDL) levels, which can lead to atherosclerosis (narrowing of the arteries) [53]. Atherosclerosis is also a disease associated with aging, where the risk of having atherosclerosis is higher with older age [72]. Therefore, dyslipidemia in the elderly can result in a very high risk of developing atherosclerosis and CVDs. Dyslipidemia can be diagnosed by testing the lipid profile, which includes measurements of four parameters: total cholesterol, HDL cholesterol, TGs, and low-density lipoproteins (LDLs). The gold standard methods to measure lipid profiles include ultracentrifugation, selective precipitation, electrophoresis, and direct measurement of the 
cholesterol triglycerides in isolated lipoprotein fractions [73]. In 2013, a sensor-based device (LipidPlus) for measurement of the lipid profile and blood glucose was approved by the FDA. The device works similarly to a glucometer, where a drop of blood is taken from the fingertip and tested. The device produces results based on reflection density and color changes in the test sensor through an enzyme reaction when blood is taken [53]. There are also different vendors, such as CardioChek, Curo L5, and LipidoCare, who provide similar devices for testing of the lipid profile, and the prices range between 50 and 200 USD, depending on the vendor [74].

\subsection{Diabetes Mellitus}

The number of people living with diabetes was 436 million in 2019, and the number is expected to reach 700 million by 2045 . About $20 \%$ of people older than 65 years of age have diabetes mellitus, and $79 \%$ of diabetes patients are living in low- and middle-income countries [75]. Moreover, diabetes is responsible for the majority of cases of blindness, renal failure, heart attacks, strokes, and lower limb amputation. The World Health Organization (WHO) has suggested that diabetes and its complications can be avoided, delayed, or treated by a healthy diet, doing regular physical activities, and regular screening and medical treatment [76]. While there are different signs and symptoms of diabetes mellitus, clinicians need the blood glucose or $\mathrm{HbA} 1 \mathrm{c}$ of the patient to confirm the diagnosis of diabetes mellitus $[27,30]$. Some other data are also required to be collected in different stages of the clinical procedure (Table 5).

Table 5. Required data and IoT availability of diabetes mellitus.

\begin{tabular}{|c|c|c|c|}
\hline IoT for Data Collection & Screening and Diagnosis & Monitoring & Follow Up \\
\hline Yes & Blood Glucose [34] & $\begin{array}{c}\text { Blood Glucose [34] } \\
\text { ECG [37] } \\
\text { Blood Pressure [35] } \\
\text { Pulse Rate [35,36] } \\
\text { Temperature [39] } \\
\text { Oxygen Saturation [35,36] } \\
\text { Lipid Profile [53] }\end{array}$ & $\begin{array}{c}\text { Blood Glucose [34] } \\
\text { ECG [37] } \\
\text { Blood Pressure [35] } \\
\text { Pulse Rate }[35,36] \\
\text { Temperature [39] } \\
\text { Oxygen Saturation }[35,36] \\
\text { Body Weight }[43] \\
\text { Urine Output for } \\
\text { Nephropathy [41,42] } \\
\text { Lipid Profile [53] }\end{array}$ \\
\hline No & HBA1C & $\begin{array}{c}\text { HBA1c } \\
\text { Chest X-ray } \\
\text { Urea and Electrolytes }\end{array}$ & $\begin{array}{c}\text { HBA1c } \\
\text { Urea and Electrolytes } \\
\text { Peripheral Pulses for } \\
\text { Ischemia (DM Foot) } \\
\text { Cataract }\end{array}$ \\
\hline
\end{tabular}

Glucometers are available in many forms for testing blood glucose instantly, using a single drop of blood from the patient. The blood glucose data can be interpreted by the clinician or self-interpretation can be done [34]. Glucometers are sensor-based blood glucose measuring devices and can easily be purchased for personal use. They are also used widely in clinical environments. Some newer models of glucometers can also be connected to other devices or mobile phones to work as medical IoT devices. However, blood glucose only represents the current blood glucose level of the patient, and it can be influenced by the most recent meal or fasting conditions. $\mathrm{HbA1c}$, on the other hand, is the gold standard for the diagnosis of diabetes mellitus and is used to analyze the blood glucose level of a patient for up to 120 days before the sample is taken [77]. HbA1c is glycated hemoglobin, and the average increase of $2 \mathrm{mmol} / \mathrm{L}$ in blood glucose can cause a rise of $11 \mathrm{mmol} / \mathrm{mol}$ in $\mathrm{HbA} 1 \mathrm{c}$ [27]. In addition to confirming the diagnosis, $\mathrm{HbA1c}$ is also a useful parameter for clinicians for monitoring people with diabetes, and it can support decisions for choosing treatment plans, according to National Institute for Health and Care Excellence (NICE) guidelines [30,78].

However, to date, $\mathrm{HbA1c}$ can only be tested by laboratory testing methods, and no IoT device or sensor is available yet. Some innovative ideas allow the testing of $\mathrm{HbA} 1 \mathrm{c}$ at home with $\mathrm{HbA} 1 \mathrm{c}$ 
home testing kits, but they cannot be used as a confirmation test due to accuracy concerns [79]. Zhang et al. [80] developed a cheap prototype for providing a point-of-care testing device to detect $\mathrm{HbA1c}$ levels for diabetics. The availability of a rapid $\mathrm{HbA1c}$ testing meter similar to a glucometer could be very helpful for clinicians and diabetic patients in managing diabetes mellitus.

There are some initiatives where a continuous glucose monitoring sensor can be combined with an insulin pump to become an artificial pancreas, which detects blood glucose levels and adjusts the insulin infusion rate independently of human operation [81]. If $\mathrm{HbA1} \mathrm{c}$ can also be measured in similar ways to blood glucose, the data can be utilized to improve the functional accuracy of an artificial pancreas for providing continuous treatment.

\subsection{Chronic Kidney Disease}

Chronic kidney disease (CKD) was ranked 27th on the global cause of death list in 1990 and rose to 18th in 2010. This increasing incident rate was second to that of HIV and AIDS [82]. Ten percent of the world population has CKD, and millions die every year due to the lack of access to affordable treatment [83]. The prevalence of CKD is high in the elderly population, with increasing risks for undesirable outcomes [84,85]. The most common causes of CKD in the United Kingdom are diabetes mellitus, glomerulonephritis, and hypertension, and patients who have CKD have a higher chance of dying from CVDs than CKD itself [30]. It is important to monitor vital signs, as well as all the other parameters, for CVDs, diabetes mellitus, and hypertension (Table 6).

The diagnosis of CKD is made by either the presence of protein albumin in the urine or calculation of the glomerular filtration rate (GFR). The various stages of CKD classification also depend on the amount of albumin present in the urine or the value of the GFR $[27,30]$. The GFR can be calculated by testing the creatinine in the blood, whose level is raised when the kidneys cannot function well to excrete it. There is a creatinine and eGFR meter available commercially for use by point-of-care personnel [49]. The eGFR meter works in a similar way to a glucometer, with a biosensor collecting a drop of blood from the fingertip. This device allows relatively painless testing of the creatinine and eGFR levels within seconds with acceptable accuracy.

Table 6. Required data and IoT availability for chronic renal disease.

\begin{tabular}{cccc}
\hline IoT for Data Collection & Screening and Diagnosis & Monitoring & Follow Up \\
\hline & & Blood Pressure [35] & ECG [37] \\
& Urine Output [41,42] & Pulse Rate [35,36] & Blood Pressure [35] \\
Yes & ECG [37] & Pulse Rate [35,36] \\
& Creatinine for Glomerular & Blood Glucose [34] & Oxygen Saturation [35,36] \\
& Filtration Rate (GFR) [49] & Flood Glucose [34] \\
& Lipid Profile [53] & Lipid Profile [53] \\
& & Lipid Profile [53] & Pulse Rhythms \\
& Pulse Rhythms & Pulse Rhythms & Cardiac Enzymes \\
Cardiac Enzymes & Cardiac Enzymes & Chest X-ray \\
No & Chest X-ray & Chest X-ray & Echocardiogram \\
& Echocardiogram & Echocardiogram & Urea and Electrolytes \\
\hline
\end{tabular}

Monitoring the fluid balance (intake and output) is one of the most important procedures in the healthcare of patients with CKD. The amount of fluid taken in by the patient, both by drinking and injecting through the veins, needs to be monitored; that is, the amount of fluid excreted by the patient needs to be monitored. The excretory function of the kidneys in CKD patients is impaired, causing reduced urine output and leading to fluid retention if the fluid intake and output are not monitored and adjusted carefully. The retention of fluid can have many harmful effects on patients, such as edema, hypertension, heart failure, and pulmonary edema. The fluid intake is monitored through the syringe pumps and infusion pumps, as well as by having a designated drinking bottle for the patient. Currently, most hospitals rely on nurses to monitor the urine output of the patients using a 
urine bag, which is susceptible to human error. There are some IoT systems and devices available for measuring urine output [41,42], but it seems that hospitals and clinicians are not very interested in using them, or they are not yet aware of the availability of such systems.

\subsection{Parkinson's Disease}

Parkinson's disease (PD) is a complex neurodegenerative disorder affecting millions of elderly people worldwide, characterized by both motor and non-motor symptoms, leading to a significant reduction in quality of life [45]. PD is diagnosed by looking at motor symptoms such as bradykinesia with a resting tremor or hypertonia [30]. See Table 7 for the required data.

A tremor is the most common symptom of Parkinson's disease (PD), with 70\% of patients having the symptom. There are two types of tremors: a resting tremor and a postural tremor, where the resting tremor is more prevalent [45]. According to Rovini, Maremmani and Cavallo [45], many types of devices and measurement methods are available for the measurement of tremors. For example, Trequant is a tremor-tracking wearable that is available commercially [48]. The IoT solution for detecting tremors is regarded as a more optimal solution, since the severity of the disease and the effectiveness of treatment can be quantified with minimal invasiveness and relatively higher reliability than a traditional visual examination done by a neurologist [86].

Early diagnosis of PD is also closely related to the detection of postural instability, which is more common in the early stages of PD [87]. The pull test is the most common clinical method used to identify postural instability with the use of the Unified Parkinson's Disease Rating Scale (UPDRS) [88]. Many researchers $[44,45]$ have mentioned that detection of postural instability in PD patients is possible. However, more research is needed to reach the stage where it can be used clinically.

Table 7. Required data and IoT availability for Parkinson's disease.

\begin{tabular}{|c|c|c|c|}
\hline IoT for Data Collection & Screening and Diagnosis & Monitoring & Follow Up \\
\hline Yes & Tremors [48] & $\begin{array}{l}\text { Postural Instability [44,45] } \\
\text { REM Sleep Disorders [38] }\end{array}$ & \\
\hline No & $\begin{array}{l}\text { Rigidity or Increased Tone } \\
\text { Bradykinesia or Hypokinesia }\end{array}$ & $\begin{array}{l}\text { Poor Executive Functioning } \\
\text { Freezing while Walking }\end{array}$ & $\begin{array}{c}\text { Depression } \\
\text { Dementia } \\
\text { Psychosis }\end{array}$ \\
\hline
\end{tabular}

\subsection{Sleep Tracking}

The prevalence of sleep disorders in elderly people is getting higher. Many elderly people face changes in sleep patterns with aging, and inadequate and inappropriate sleep can affect their quality of life. As the importance of sleep in elderly healthcare has been progressively recognized [89], it is becoming more important to understand and monitor the sleep patterns of elderly patients. The gold standard of sleep monitoring methods is polysomnography, done in a sleep laboratory and performed by sleep technologists. The method consists of at least seven channels for data collection. The main benefit of this method is standardization, using the American Academy of Sleep Medicine's practice parameters for polysomnography [90].

Consumer sleep-tracking devices, on the other hand, mostly depend on the smartphone's built-in sensors and apps to detect sleep through movement data. Some combine additional sensors, where the sensors are put near the bed (e.g., the mattress, pillow, and nightstand) or worn on the body. The biggest barrier for consumer sleep-tracking devices is a lack of standardization [90]. According to Sadek, Demarasse, and Mokhtari [38], sleep-tracking devices have not reached the same standard criteria as independent devices for clinical application. However, they can provide longitudinal data that cannot be done by the sleep laboratory method. The combination of wearable devices and bed-based sensors in a multimodal sensing approach could provide continuous sleep monitoring as well as vital activities [38]. 


\subsection{Monitoring of Treatment and Rehabilitation}

This section deals with treatment given by oral medications and injections. For many elderly patients with chronic diseases, taking oral medication regularly is crucial for staying healthy, but they may forget or otherwise not adhere to the correct regime. According to [91], forgetfulness is identified as a medication nonadherence related factor by $38.8 \%$ of the elderly. Consequently, many types of research were done on smart medication reminder systems and smart medication pillboxes [92-94]. The same concept could be applied in the hospital care setting to remind the nurses about giving medications and injections at the right time to the right patient. This could reduce the pressure on nurses and support best practices in drug administration and recordkeeping. It could also reduce human errors. Injection pumps and infusion pumps also play an important role in providing precisely controlled treatment to the patient. A device such as an insulin pump can be very helpful for patients with diabetes mellitus in controlling blood glucose levels easily and continuously [95]. These devices can automatically record the dose given and monitor the patterns of use.

Rehabilitation is an important intervention for patients after illnesses, such as heart attacks and strokes, or falls. The role of IoT applications in rehabilitation has also become very popular, with research being done in many fields such as virtual reality and sensor-integrated systems [96], telerehabilitation using Kinect sensors and wearable sensors [97,98], the inclusion of games in physiotherapy, and smart homes designed for rehabilitation and accident prevention [99-102].

\section{Conclusions}

The purpose of this research was to explore the usage of IoT devices and applications in elderly health from a clinical perspective, for which identifying the types of data for common diseases was required. Then, the required data for clinical examinations and diagnoses were mapped to the available IoT applications and their collected data types and accuracy.

This study has identified 20 types of data that can be collected by available IoT technologies and 38 types of data that cannot. The most important finding to emerge from this study is that there are many types of data needed for clinical care of the elderly which cannot be collected by the IoT devices and sensors available today. This finding indicates research opportunities for information technology (IT) professionals and developers in the future. This paper has also discussed the accuracy of the data collected by IoT devices for application in clinical settings.

The findings of this research identify many types of data that are rarely, if ever, collected via wearable or IoT devices in the elder care area. The results could be useful for researchers and technologists in understanding the clinical needs that are not currently met by current devices. This research paper also aims to inform clinicians about IoT technologies currently available that could support the care of older people in a range of common diseases.

Besides some technical and clinical challenges that have been discussed in this paper, data security and privacy [103] and the standardization of data [104] are among the top barriers of full implementation and utilization of IoT applications in healthcare in general and in elderly care in particular.

Several critical security and privacy concerns appeared with the growing applications of the IoT [103], especially in healthcare. Health data collection with the IoT has privacy issues, since people's private information can be gathered without being noticed by the individual [105]. Since IoT devices are placed in open and outdoor spaces, they can be easily accessed by anyone, exposing them to physical threats [106]. Sensitive medical records and personal information can also be captured by attackers if security settings are not properly implemented, leading to a threat to user privacy and data security [107]. Moreover, IoT devices have small storage capacities and computing power, which also makes it harder to implement high-level security settings [108]. There is no global policy or standard for IoT interaction or the implementation of its applications, resulting in a variety of applications having a variety of authentication methods. This makes the IoT hard to integrate for the assurance of data privacy and security [106]. Although many research studies have been done to address the security and privacy problems of the IoT and wearable devices, the complex nature of an IoT device 
network makes the design and implementation of an effective, interoperable, and updatable security system difficult [108].

On the other hand, most of the data collected by IoT devices are not integrated. These data are normally being stored, analyzed, and used separately, using diverse information systems developed by separate vendors. Interoperability is probably the only sustainable solution for integrating and delivering quality healthcare [109]. However, there is no unique technical standard available to date for universal health data communication [110]. Some organizations such as Health Level 7 (HL7) and SNOMED CT are trying to achieve a comprehensive framework and standard for health information management and communication between wearable medical devices.

The Fast Healthcare Interoperability Resources (FHIR) standard has been developed very recently, with the aim of compatibility for newer technologies such as smartphones, the IoT, and wearable medical devices [111]. The FHIR standard's use of the Representational State Transfer (REST) architectural style should be adopted for devices with limited processing capabilities, such as medical sensors and mobile healthcare applications, because they are more lightweight by design compared with Simple Object Access Protocol (SOAP) technologies [110]. The FHIR standard is particularly approachable for building healthcare mobile applications.

The next step in this research may be to improve the accuracy of IoT devices that are not ready to be used in clinical settings and identify a certification process for them. Future research could also focus on the development of IoT devices for collecting essential data in specific areas, such as HbA1c for diabetes mellitus and cardiac enzymes for coronary artery diseases.

Author Contributions: The research study was conceptualized by S.M.; S.Y.Y.T. carried out the data analysis part under the supervision of S.M. and D.P.; The original report draft was prepared by S.Y.Y.T.; writing-review and editing, S.M. and D.P. All authors have read and agreed to the published version of the manuscript.

Funding: This research was funded by the AUT School of Engineering, Computer and Mathematical Sciences, Faculty of Design and Creative Technology as part of the Summer Research Assistant Awards 2019.

Conflicts of Interest: The authors declare no conflict of interest. 


\section{Appendix A}

Table A1. The common diseases among the elderly population and the required data in each stage of clinical procedures

\begin{tabular}{|c|c|c|c|}
\hline Disease & Screening and Diagnosis & Monitoring & Follow Up \\
\hline & $\begin{array}{l}\text { Which data helps or supports clinicians } \\
\text { for early diagnosis? }\end{array}$ & $\begin{array}{l}\text { Which data helps to measure that the patient is } \\
\text { responding well to treatment? }\end{array}$ & $\begin{array}{c}\text { What types of data are needed to access in a } \\
\text { follow up? }\end{array}$ \\
\hline Coronary Heart Disease & $\begin{array}{ll}\text { - } & \text { ECG } \\
\text { - } & \text { Cardiac Enzymes } \\
\text { - } & \text { Chest X-ray } \\
\text { - } & \text { Echocardiogram } \\
\text { - } & \text { Pulse Rate and Rhythms } \\
\text { - } & \text { Temperature } \\
\text { - } & \text { Oxygen Saturation } \\
\text { - } & \text { Blood Glucose } \\
\text { - } & \text { Lipid Profile } \\
\text { - } & \text { Urea and Electrolytes }\end{array}$ & $\begin{array}{ll}\text { - } & \text { ECG (Continuous) } \\
\text { - } & \text { Cardiac Enzymes } \\
\text { - } & \text { Chest X-ray } \\
\text { - } & \text { Echocardiogram } \\
\text { - } & \text { Plood Pressure } \\
\text { - } & \text { Temperature } \\
\text { - } & \text { Oxygen Saturation } \\
\text { - } & \text { Blood Glucose } \\
\text { - } & \text { Lipid Profile } \\
\text { - } & \text { Urea and Electrolytes }\end{array}$ & $\begin{array}{ll}\text { - } & \text { ECG } \\
\text { - } & \text { Chest X-ray } \\
\text { - } & \text { Echocardiogram } \\
\text { - } & \text { Blood Pressure } \\
\text { - } & \text { Pulse Rate and Rhythms } \\
\text { - } & \text { Oxygen Saturation } \\
\text { - } & \text { Blood Glucose } \\
\text { - } & \text { Lipid Profile } \\
\text { - } & \text { Urea and Electrolytes }\end{array}$ \\
\hline Stroke & $\begin{array}{ll}\text { - } & \text { CT/CT Angiogram } \\
\text { - } & \text { MRI/MR Angiogram } \\
\text { - } & \text { ECG } \\
\text { - } & \text { Echocardiogram } \\
\text { - } & \text { Blood Pressure } \\
\text { - } & \text { Pulse Rate and Rhythms } \\
\text { - } & \text { Temperature } \\
\text { - } & \text { Oxygen Saturation } \\
\text { - } & \text { Blood Glucose } \\
\text { - } & \text { Lipid Profile } \\
\text { - } & \text { Full Blood Count } \\
\text { - } & \text { ESR }\end{array}$ & $\begin{array}{ll}\text { - } & \text { Conscious Level } \\
\text { - } & \text { ECG } \\
\text { - } & \text { Blood Pressure } \\
\text { - } & \text { Pulse Rate and Rhythms } \\
\text { - } & \text { Temperature } \\
\text { - } & \text { Oxygen Saturation } \\
\text { - } & \text { Aspiration } \\
\text { - } & \text { Constipary Retention and Incontinence } \\
\text { - } & \text { Posture } \\
\text { - } & \text { Gait }\end{array}$ & $\begin{array}{ll}\text { - } & \text { Conscious Level } \\
\text { - } & \text { ECG } \\
\text { - } & \text { Blood Pressure } \\
\text { - } & \text { Pulse Rate and Rhythms } \\
\text { - } & \text { Temperature } \\
\text { - } & \text { Aspgiration } \\
\text { - } & \text { Urinary Retention and Incontinence } \\
\text { - } & \text { Constipation and Bowel Incontinence } \\
\text { - } & \text { Posture (Proper Positioning) } \\
\text { - } & \text { Gait } \\
\text { - } & \text { Pressure Ulcers }\end{array}$ \\
\hline
\end{tabular}


Table A1. Cont.

\begin{tabular}{|c|c|c|c|}
\hline Disease & Screening and Diagnosis & Monitoring & Follow Up \\
\hline Diabetes Mellitus & $\begin{array}{ll}\text { - } & \text { Blood Glucose } \\
\text { - } & \text { HBA1C }\end{array}$ & $\begin{array}{ll}\text { - } & \text { Blood Glucose } \\
\text { - } & \text { HBA1C } \\
\text { - } & \text { CCG } \\
\text { - } & \text { Blost X-ray } \\
\text { - } & \text { Pulse Rate } \\
\text { - } & \text { Temperature } \\
\text { - } & \text { Oxygen Saturation } \\
\text { - } & \text { Lipid Profile } \\
\text { - } & \text { Urea and Electrolytes }\end{array}$ & $\begin{array}{ll}\text { - } & \text { Blood Glucose } \\
\text { - } & \text { HBA1C } \\
\text { - } & \text { ECG } \\
\text { - } & \text { Blood Pressure } \\
\text { - } & \text { Pulse Rate } \\
\text { - } & \text { Temperature } \\
\text { - } & \text { Oxygen Saturation } \\
\text { - } & \text { Lipid Profile } \\
\text { - } & \text { Urea and Electrolytes } \\
\text { - } & \text { Cataract and Vision } \\
\text { - } & \text { Urine Output for Nephropathy } \\
\text { - } & \text { Weight } \\
\text { - } & \text { Peripheral Pulses for Ischemia } \\
& \text { (DM Foot) }\end{array}$ \\
\hline Hypertension & $\begin{array}{ll}\text { - } & \text { Blood Pressure } \\
\text { - } & \text { Pulse Rate and Rhythms } \\
\text { - } & \text { ECG }\end{array}$ & $\begin{array}{ll}\text { - } & \text { Blood Pressure } \\
\text { - } & \text { Pulse Rate and Rhythms } \\
\text { - } & \text { ECG } \\
\text { - } & \text { Lipid Profile } \\
\text { - } & \text { Echocardiogram } \\
\text { - } & \text { Blood Glucose }\end{array}$ & $\begin{array}{ll}\text { - } & \text { Blood Pressure } \\
\text { - } & \text { Pulse Rate and Rhythms } \\
\text { - } & \text { ECG } \\
\text { - } & \text { Lipid Profile } \\
\text { - } & \text { Echocardiogram } \\
\text { - } & \text { Blood Glucose } \\
\text { - } & \text { Thyroid Function } \\
\text { - } & \text { Ultrasound } \\
\text { - } & \text { Urea and Electrolytes }\end{array}$ \\
\hline
\end{tabular}


Table A1. Cont.

\begin{tabular}{|c|c|c|c|}
\hline Disease & Screening and Diagnosis & Monitoring & Follow Up \\
\hline Chronic Renal Disease & $\begin{array}{ll}\text { - } & \text { Glomerular Filtration Rate (GFR) } \\
\text { - Urine Output }\end{array}$ & $\begin{array}{ll}\text { - } & \text { Blood Pressure } \\
\text { - } & \text { Pulse Rate and Rhythms } \\
\text { - } & \text { ECG } \\
\text { - } & \text { Blood Glucose } \\
\text { - } & \text { Fluid Intake and Output } \\
\text { - } & \text { Hemoglobin } \\
\text { - } & \text { Urea and Electrolytes } \\
\text { - } & \text { Ultrasound }\end{array}$ & $\begin{array}{ll}\text { - } & \text { Blood Pressure } \\
\text { - } & \text { Pulse Rate and Rhythms } \\
\text { - } & \text { BCG } \\
\text { - } & \text { Fluid Intake and Output } \\
\text { - } & \text { Hemoglobin } \\
\text { - } & \text { Urea and Electrolytes } \\
\text { - } & \text { Ultrasound }\end{array}$ \\
\hline Delirium & $\begin{array}{ll}\text { - } & \text { Full Blood Count } \\
\text { - } & \text { Urea and Electrolytes } \\
\text { - } & \text { Liver Function Test } \\
\text { - } & \text { Blood Glucose } \\
\text { - } & \text { Arterial Blood Gas } \\
\text { - } & \text { Septic Screen } \\
\text { - } & \text { ECG } \\
\text { - } & \text { Malaria } \\
\text { - } & \text { Lumbar Puncture } \\
\text { - } & \text { EEG } \\
\text { - } & \text { CT/MRI }\end{array}$ & $\begin{array}{ll}\text { - } & \text { Disordered Thinking } \\
\text { - } & \text { Euphoric, Fearful, Depressed, or Angry } \\
\text { - } & \text { Language Impaired } \\
\text { - } & \text { Reversal of Sleep-Wake Cycle } \\
\text { - } & \text { Inattention } \\
\text { - } & \text { Unaware or Disorientated } \\
\text { - } & \text { Memory Deficits }\end{array}$ & $\begin{array}{ll}\text { - } & \text { Disordered Thinking } \\
\text { - } & \text { Euphoric, Fearful, Depressed, or Angry } \\
\text { - } & \text { Language Impaired } \\
\text { - } & \text { Reversal of Sleep-Wake Cycle } \\
\text { - } & \text { Inattention } \\
\text { - } & \text { Unaware or Disorientated } \\
\text { - } & \text { Memory Deficits }\end{array}$ \\
\hline Parkinson's Disease & $\begin{array}{ll}\text { - } & \text { Tremor } \\
\text { - } & \text { Rigidity and Increased Tone } \\
\text { Bradykinesia and Hypokinesia }\end{array}$ & $\begin{array}{ll}\text { - } & \text { Postural Instability } \\
\text { - } & \text { Poor Executive Functioning } \\
\text { - } & \text { REM Sleep Disorders } \\
\text { - } & \text { Freezing while Walking }\end{array}$ & $\begin{array}{ll}\text { - } & \text { Depression } \\
\text { - } & \text { Dementia } \\
& \text { Psychosis }\end{array}$ \\
\hline Falls & $\begin{array}{l}\text { - } \quad \text { Early Detection is Critical } \\
\text { X-ray for Fractures }\end{array}$ & $\begin{array}{ll}\text { - } & \text { Muscle Strength } \\
\text { - } & \text { Balance } \\
\text { - } & \text { Vision or Cognitive Function }\end{array}$ & \\
\hline
\end{tabular}




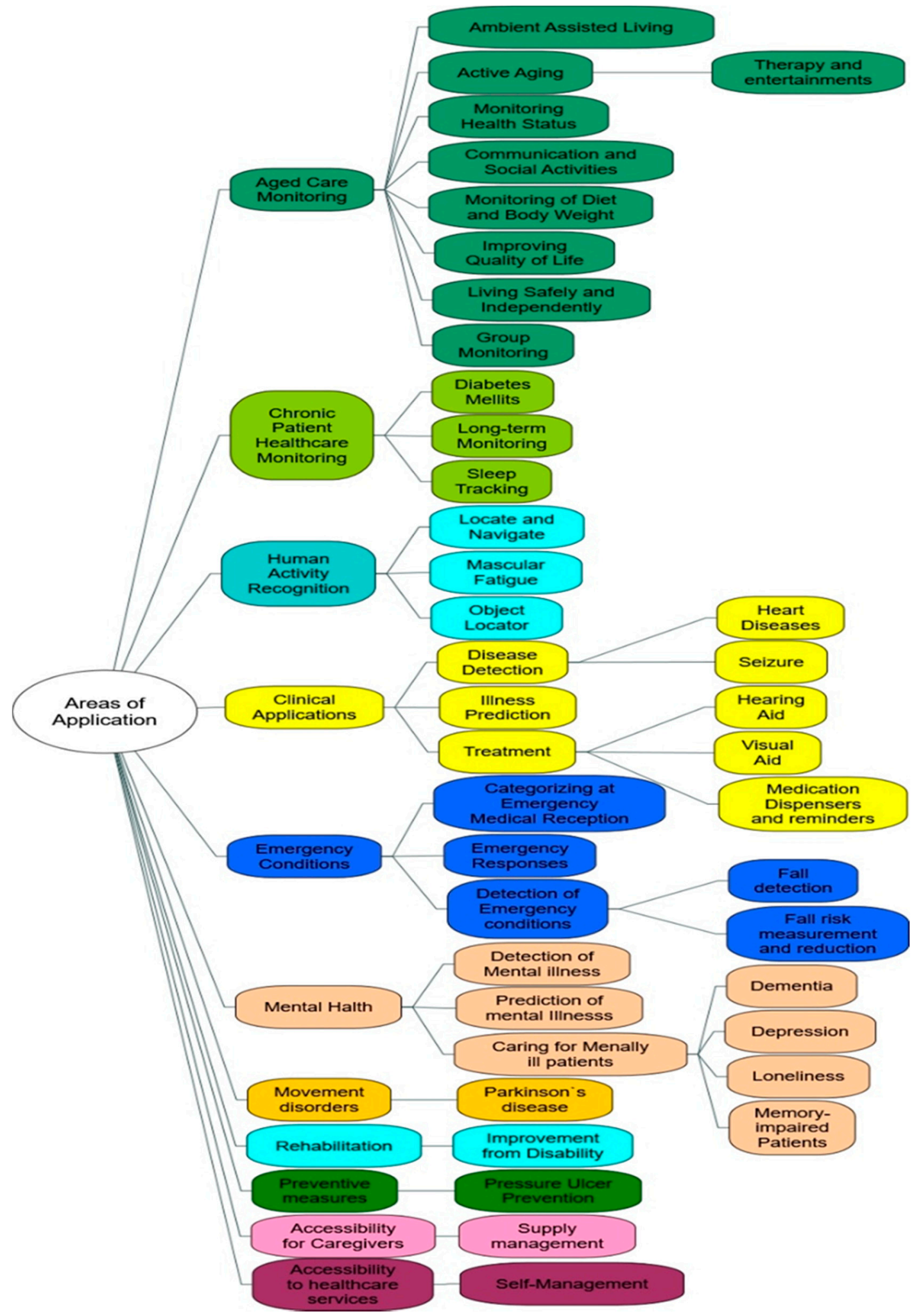

Figure A1. The hierarchy of IoT applications for elderly healthcare [7]. 
Table A2. IoT availability for data collection in the identified diseases.

\begin{tabular}{|c|c|c|c|c|}
\hline Disease & $\begin{array}{l}\text { Do We Have Any IoT to } \\
\text { Support in Getting the Data? }\end{array}$ & Screening and Diagnosis & Monitoring & Follow Up \\
\hline \multirow{2}{*}{ 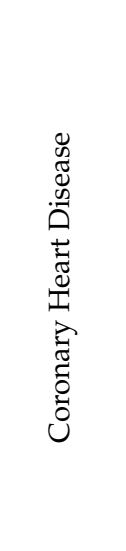 } & Yes & $\begin{array}{ll}\text { - } & \text { ECG } \\
\text { - } & \text { Blood Pressure } \\
\text { - } & \text { Pulse Rate } \\
\text { - } & \text { Temperature } \\
\text { - } & \text { Oxygen Saturation } \\
\text { - } & \text { Lipid Profile }\end{array}$ & $\begin{array}{ll}\text { - } & \text { ECG (Continuous) } \\
\text { - } & \text { Blood Pressure } \\
\text { - } & \text { Pulse Rate } \\
\text { - } & \text { Temperature } \\
\text { - } & \text { Bxygen Saturation } \\
\text { - } & \text { Lipid Profile }\end{array}$ & $\begin{array}{ll}\text { - } & \text { ECG } \\
\text { - } & \text { Blood Pressure } \\
\text { - } & \text { Pulse Rate } \\
\text { - } & \text { Oxygen Saturation } \\
\text { - } & \text { Blood Glucose } \\
\text { - } & \text { Lipid Profile }\end{array}$ \\
\hline & No & $\begin{array}{ll}\text { - } & \text { Pulse Rhythms } \\
\text { - } & \text { Cardiac Enzymes } \\
\text { - } & \text { Chest X-ray } \\
\text { - } & \text { Echocardiogram } \\
\text { - } & \text { Urea and Electrolytes }\end{array}$ & $\begin{array}{ll}\text { - } & \text { Pulse Rhythms } \\
\text { - } & \text { Cardiac Enzymes } \\
\text { - } & \text { Chest X-ray } \\
\text { - } & \text { Echocardiogram } \\
\text { - } & \text { Urea and Electrolytes }\end{array}$ & $\begin{array}{l}\text { - } \quad \text { Pulse Rhythms } \\
\text { - } \quad \text { Chest X-ray } \\
\text { - } \quad \text { Echocardiogram } \\
\text { - }\end{array}$ \\
\hline \multirow{2}{*}{$\begin{array}{l}\ddot{v} \\
\text { o } \\
\text { के }\end{array}$} & Yes & $\begin{array}{ll}\text { - } & \text { ECG } \\
\text { - } & \text { Blood Pressure } \\
\text { - } & \text { Pulse Rate } \\
\text { - } & \text { Temperature } \\
\text { - } & \text { Oxygen Saturation } \\
\text { - } & \text { Blood Glucose } \\
\text { - } & \text { Lipid Profile }\end{array}$ & $\begin{array}{ll}\text { - } & \text { ECG } \\
\text { - } & \text { Blood Pressure } \\
\text { - } & \text { Pulse Rate } \\
\text { - } & \text { Temperature } \\
\text { - } & \text { Oxygen Saturation } \\
\text { - } & \text { Gait }\end{array}$ & $\begin{array}{ll}\text { - } & \text { ECG } \\
\text { - } & \text { Blood Pressure } \\
\text { - } & \text { Pulse Rate } \\
\text { - } & \text { Temperature } \\
\text { - } & \text { Oxygen Saturation } \\
\text { - } & \text { Pressure Ulcers } \\
\text { - } & \text { Gait }\end{array}$ \\
\hline & No & $\begin{array}{ll}- & \text { CT/CT Angiogram } \\
\text { - } & \text { MRI/MR Angiogram } \\
\text { - } & \text { Echocardiogram } \\
\text { - } & \text { Full Blood Count } \\
\text { - } & \text { ESR } \\
& \text { Pulse Rhythms }\end{array}$ & $\begin{array}{ll}\text { - } & \text { Conscious Level } \\
\text { - } & \text { Pulse Rhythms } \\
\text { - } & \text { Aspiration } \\
\text { - } & \text { Urinary Retention and Incontinence } \\
\text { - } & \text { Constipation and Bowel Incontinence } \\
\text { - } & \text { Posture }\end{array}$ & $\begin{array}{ll}\text { - } & \text { Conscious Level } \\
\text { - } & \text { Pulse Rhythms } \\
\text { - } & \text { Aspiration } \\
\text { - } & \text { Urinary Retention and Incontinence } \\
\text { - } & \text { Ponstipation and Bowel Incontinence } \\
\text { Proper Positioning) }\end{array}$ \\
\hline
\end{tabular}


Table A2. Cont.

\begin{tabular}{|c|c|c|c|c|}
\hline Disease & $\begin{array}{l}\text { Do We Have Any IoT to } \\
\text { Support in Getting the Data? }\end{array}$ & Screening and Diagnosis & Monitoring & Follow Up \\
\hline \multirow[t]{2}{*}{ 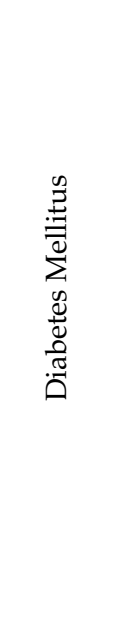 } & Yes & - $\quad$ Blood Glucose & $\begin{array}{ll}\text { - } & \text { Blood Glucose } \\
\text { - } & \text { ECG } \\
\text { - } & \text { Blood Pressure } \\
\text { - } & \text { Pulse Rate } \\
\text { - } & \text { Temperature } \\
\text { - } & \text { Lipid Profile }\end{array}$ & $\begin{array}{ll}\text { - } & \text { Blood Glucose } \\
\text { - } & \text { BCG } \\
\text { - } & \text { Puodse Rate } \\
\text { - } & \text { Temperature } \\
\text { - } & \text { Oxygen Saturation } \\
\text { - } & \text { Body Weight } \\
\text { - } & \text { Urine Output for Nephropathy } \\
\text { - } & \text { Lipid Profile }\end{array}$ \\
\hline & No & - $\quad$ HBA1C & $\begin{array}{ll}\text { - } & \text { HBA1C } \\
\text { - } & \text { Chest X-ray } \\
\text { - } & \text { Urea and Electrolytes }\end{array}$ & $\begin{array}{ll}\text { - } & \text { HBA1C } \\
\text { - } & \text { Urea and Electrolytes } \\
\text { Peripheral Pulses for Ischemia } & \text { (DM Foot) } \\
\text { - } & \text { Cataract }\end{array}$ \\
\hline \multirow{2}{*}{ 离 } & Yes & $\begin{array}{ll}\text { - } & \text { Blood Pressure } \\
\text { - } & \text { Pulse rate } \\
\text { - } & \text { ECG }\end{array}$ & $\begin{array}{ll}\text { - } & \text { Blood Pressure } \\
\text { - } & \text { Pulse Rate } \\
\text { - } & \text { ECG } \\
\text { - } & \text { Blood Glucose }\end{array}$ & $\begin{array}{ll}\text { - } & \text { Blood Pressure } \\
\text { - } & \text { Pulse Rate } \\
\text { - } & \text { ECG } \\
\text { - } & \text { Blood Glucose } \\
\text { - } & \text { Lipid Profile }\end{array}$ \\
\hline & No & - $\quad$ Pulse Rhythms & - $\quad$ Pulse Rhythms & $\begin{array}{ll}\text { - } & \text { Pulse Rhythms } \\
\text { - } & \text { Echocardiogram } \\
\text { - } & \text { Thyroid Function } \\
\text { - } & \text { Urea and Electrolytes } \\
\text { - } & \text { Ultrasound }\end{array}$ \\
\hline
\end{tabular}


Table A2. Cont.

\begin{tabular}{|c|c|c|c|c|}
\hline Disease & $\begin{array}{l}\text { Do We Have Any IoT to } \\
\text { Support in Getting the Data? }\end{array}$ & Screening and Diagnosis & Monitoring & Follow Up \\
\hline 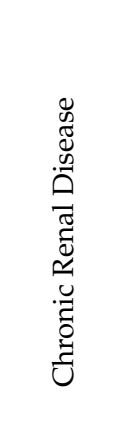 & Yes & $\begin{array}{ll}\text { - } & \text { Urine Output } \\
\text { - } & \text { Creatinine for Glomerular } \\
\text { Filtration Rate (GFR) }\end{array}$ & $\begin{array}{ll}\text { - } & \text { Blood Pressure } \\
\text { - } & \text { Pulse Rate } \\
\text { - } & \text { ECG } \\
\text { - } & \text { Blood Glucose } \\
\text { - } & \text { Fluid Intake and Output }\end{array}$ & $\begin{array}{ll}\text { - } & \text { Blood Pressure } \\
\text { - } & \text { Pulse Rate } \\
\text { - } & \text { ECG } \\
\text { - } & \text { Blood Glucose } \\
\text { - } & \text { Fluid Intake and Output }\end{array}$ \\
\hline$\frac{\Xi}{:}$ & Yes & $\begin{array}{ll}\text { - } & \text { Blood Glucose } \\
\text { - } & \text { ECG } \\
\text { - } & \text { EEG }\end{array}$ & - Reversal of Sleep-Wake Cycle & - Reversal of Sleep-Wake Cycle \\
\hline
\end{tabular}


Table A2. Cont.

\begin{tabular}{|c|c|c|c|c|}
\hline Disease & $\begin{array}{l}\text { Do We Have Any IoT to } \\
\text { Support in Getting the Data? }\end{array}$ & Screening and Diagnosis & Monitoring & Follow Up \\
\hline \multirow{2}{*}{ 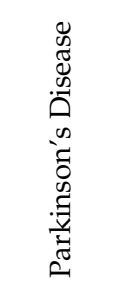 } & Yes & - $\quad$ Tremor & $\begin{array}{ll}\text { - } & \text { Postural Instability } \\
\text { - } & \text { REM Sleep Disorders }\end{array}$ & \\
\hline & No & $\begin{array}{ll}\text { - } & \text { Rigidity/increased tone } \\
\text { - } & \text { Bradykinesia/hypokinesia }\end{array}$ & $\begin{array}{l}\text { - } \quad \text { Poor Executive Functioning } \\
\text { - } \quad \text { Freezing while Walking }\end{array}$ & $\begin{array}{ll}\text { - } & \text { Depression } \\
\text { - } & \text { Dementia } \\
\text { - } & \text { Psychosis }\end{array}$ \\
\hline \multirow{2}{*}{$\stackrel{0}{\bar{\sigma}}$} & Yes & - $\quad$ Early Detection of falls & - Balance & \\
\hline & No & - X-ray for Fracture & $\begin{array}{l}\text { - Vision or Cognitive Function } \\
\text { - } \quad \text { Muscle Strength }\end{array}$ & \\
\hline
\end{tabular}




\section{References}

1. Cho, J. Current Status and Prospects of Health-Related Sensing Technology in Wearable Devices. J. Health Eng. 2019, 2019, 3924508. [CrossRef] [PubMed]

2. Brüssow, H. What is health? Microb. Biotechnol. 2013, 6, 341-348. [CrossRef] [PubMed]

3. United Nations. World Population Ageing 2019: Highlights; Department of Economic and Social Affairs, Population Division: New York, NY, USA, 2019.

4. Super Seniors. Our Aging Population. Available online: http://www.superseniors.msd.govt.nz/aboutsuperseniors/media/key-statistics.html (accessed on 11 January 2020).

5. De Meijer, C.; Wouterse, B.; Polder, J.; Koopmanschap, M. The effect of population aging on health expenditure growth: A critical review. Eur. J. Ageing 2013, 10, 353-361. [CrossRef] [PubMed]

6. Ghosh, K.; Dohan, M.; Veldandi, H. Digital Transformation Strategies for Healthcare Providers: Perspectives from Senior Leadership. In Proceedings of the 24th Americas Conference on Information Systems, New Orleans, LA, USA, 16 August 2018.

7. Tun, S.Y.Y.; Madanian, S.; Mirza, F. Internet of things (IoT) applications for elderly care: A reflective review. Aging Clin. Exp. Res. 2020, 1-13. [CrossRef] [PubMed]

8. Nikou, S.; Agahari, W.; Keijzer-Broers, W.; De Reuver, M. Digital healthcare technology adoption by elderly people: A capability approach model. Telemat. Inform. 2020, 53, 101315. [CrossRef]

9. Al-Khafajiy, M.; Baker, T.; Chalmers, C.; Asim, M.; Kolivand, H.; Fahim, M.; Waraich, A. Remote health monitoring of elderly through wearable sensors. Multimed. Tools Appl. 2019, 78, 24681-24706. [CrossRef]

10. Pinto, S.; Cabral, J.; Gomes, T. We-care: An IoT-based health care system for elderly people. In Proceedings of the 2017 IEEE International Conference on Industrial Technology (ICIT), Toronto, ON, Canada, 22-25 March 2017; pp. 1378-1383.

11. Islam, S.M.R.; Kwak, D.; Kabir, H.; Hossain, M.; Kwak, K.-S. The Internet of Things for Health Care: A Comprehensive Survey. IEEE Access 2015, 3, 678-708. [CrossRef]

12. Reddy, S. Can tech speed up emergency room care. Wall Street J. 2017. Available online: https://www.wsj. com/articles/can-tech-speed-up-emergency-room-care-1490629118 (accessed on 23 August 2017).

13. Maeng, D.D.; Starr, A.E.; Tomcavage, J.F.; Sciandra, J.; Salek, D.; Griffith, D. Can telemonitoring reduce hospitalization and cost of care? A health plan's experience in managing patients with heart failure. Popul. Health Manag. 2014, 17, 340-344. [CrossRef]

14. Wagner, F.; Basran, J.; Bello-Haas, V.D. A Review of Monitoring Technology for Use with Older Adults. J. Geriatr. Phys. Ther. 2012, 35, 28-34. [CrossRef]

15. Madanian, S.; Nguyen, H.H.; Mirza, F. Wearable Technology. In Encyclopedia of Gerontology and Population Aging; Gu, D., Dupre, M.E., Eds.; Springer International Publishing: Cham, Germany, 2019; pp. 1-8. [CrossRef]

16. Habibzadeh, H.; Dinesh, K.; Shishvan, O.R.; Boggio-Dandry, A.; Sharma, G.; Soyata, T. A Survey of Healthcare Internet of Things (HIoT): A Clinical Perspective. IEEE Internet Things J. 2019, 7, 53-71. [CrossRef]

17. Savvy. The Potentials and Pitfalls of the Artificial Pancreas. Available online: https://blogs.lt.vt.edu/savvy/ potentials-pitfalls-artificial-pancreas/ (accessed on 25 September 2019).

18. Wang, Z.; Yang, Z.; Dong, T. A Review of Wearable Technologies for Elderly Care that Can Accurately Track Indoor Position, Recognize Physical Activities and Monitor Vital Signs in Real Time. Sensors 2017, $17,341$. [CrossRef] [PubMed]

19. Mukhopadhyay, S.C. Wearable Sensors for Human Activity Monitoring: A Review. IEEE Sens. J. 2015, 15, 1321-1330. [CrossRef]

20. Azimi, I.; Rahmani, A.; Liljeberg, P.; Tenhunen, H. Internet of things for remote elderly monitoring: A study from user-centered perspective. J. Ambient. Intell. Humaniz. Comput. 2016, 8, 273-289. [CrossRef]

21. Pal, D.; Funilkul, S.; Charoenkitkarn, N.; Kanthamanon, P. Internet-of-Things and Smart Homes for Elderly Healthcare: An End User Perspective. IEEE Access 2018, 6, 10483-10496. [CrossRef]

22. Foster, K.R.; Torous, J. The Opportunity and Obstacles for Smartwatches and Wearable Sensors. IEEE Pulse 2019, 10, 22-25. [CrossRef]

23. Erdmier, C.; Hatcher, J.; Lee, M. Wearable device implications in the healthcare industry. J. Med. Eng. Technol. 2016, 40, 141-148. [CrossRef] 
24. Horwitz, L. Line between Consumer Wellness and Traditional Medicine Blurs Further. Available online: https://www.iotworldtoday.com/2020/01/28/line-between-consumer-wellness-and-traditionalmedicine-blurs-further/ (accessed on 1 November 2020).

25. Cruzes, D.S.; Dybå, T.; Runeson, P.; Höst, M. Case studies synthesis: A thematic, cross-case, and narrative synthesis worked example. Empir. Softw. Eng. 2015, 20, 1634-1665. [CrossRef]

26. Khan, S.; Van Wynsberghe, R. Cultivating the under-mined: Cross-case analysis as knowledge mobilization. Forum Qual. Soz. Forum Qual. Soc. Res. 2008, 9. [CrossRef]

27. Ralston, S.H.; Penman, I.D.; Strachan, M.W.; Hobson, R. Davidson's Principles and Practice of Medicine, 23rd ed.; Elsevier Health Sciences: Edinburgh, UK, 2018.

28. Mizokami, F.; Koide, Y.; Noro, T.; Furuta, K. Polypharmacy with Common Diseases in Hospitalized Elderly Patients. Am. J. Geriatr. Pharmacother. 2012, 10, 123-128. [CrossRef]

29. Lee, P.; Cigolle, C.; Blaum, C. The Co-Occurrence of Chronic Diseases and Geriatric Syndromes: The Health and Retirement Study. J. Am. Geriatr. Soc. 2009, 57, 511-516. [CrossRef] [PubMed]

30. Wilkinson, I.B.; Raine, T.; Wiles, K.; Goodhart, A.; Hall, C.; O’Neill, H. Oxford Handbook of Clinical Medicine; Oxford University Press: Tonbridge, UK, 2017.

31. Wockel, A.; Albert, U.-S.; Janni, W.; Scharl, A.; Kreienberg, R.; Stüber, T. The Screening, Diagnosis, Treatment, and Follow-Up of Breast Cancer. Dtsch. Aerzteblatt Online 2018, 115, 316-323. [CrossRef]

32. Wöckel, A.; Festl, J.; Stüber, T.; Brust, K.; Stangl, S.; Heuschmann, P.U.; Albert, U.-S.; Budach, W.; Follmann, M.; Janni, W.; et al. Interdisciplinary Screening, Diagnosis, Therapy and Follow-up of Breast Cancer. Guideline of the DGGG and the DKG (S3-Level, AWMF Registry Number 032/045OL, December 2017)_Part 1 with Recommendations for the Screening, Diagnosis and Therapy of Breast Cancer. Geburtshilfe Frauenheilkd. 2018, 78, 927-948. [CrossRef]

33. McDonagh, T.; Damy, T.; Doehner, W.; Lam, C.S.; Sindone, A.; Van Der Meer, P.; Cohen-Solal, A.; Kindermann, I.; Manito, N.; Pfister, O.; et al. Screening, diagnosis and treatment of iron deficiency in chronic heart failure: Putting the 2016 European Society of Cardiology heart failure guidelines into clinical practice. Eur. J. Hear. Fail. 2018, 20, 1664-1672. [CrossRef] [PubMed]

34. Pickering, D.; Marsden, J. How to measure blood glucose. Community Eye Heal. 2014, 27, 56-57.

35. Kunzmann, K. FDA Approves First Cuffless Blood Pressure Monitoring Devices. Available online: https://www.mdmag.com/medical-news/fda-cuffless-blood-pressure-monitoring-devices (accessed on 31 January 2020).

36. Lovett, L. FDA Clears Respiration Rate Measurement for Masimo's Home Finger Pulse Oximeter. Available online: https://www.mobihealthnews.com/content/fda-clears-respiration-rate-measurementmasimos-home-finger-pulse-oximeter (accessed on 31 January 2020).

37. Isakadze, N.; Martin, S.S. How useful is the smartwatch ECG? Trends Cardiovasc. Med. 2020, 30, 442-448. [CrossRef]

38. Sadek, I.; Demarasse, A.; Mokhtari, M. Internet of things for sleep tracking: Wearables vs. nonwearables. Heal. Technol. 2019, 10, 333-340. [CrossRef]

39. U.S. Food \& Drug Administration. Non-Contact Infrared Thermometers. Available online: https://www.fda. gov/medical-devices/general-hospital-devices-and-supplies/non-contact-infrared-thermometers (accessed on 6 October 2020).

40. Moran, D.S.; Mendal, L. Core Temperature Measurement: Methods and Current Insights. Sports Med. 2002, 32, 879-885. [CrossRef]

41. Goldman, A.; Azran, H.; Stern, T.; Grinstein, M.; Wilner, D. A Novel Electronic Device for Measuring Urine Flow Rate: A Clinical Investigation. Clin. Med. Insights Trauma Intensiv. Med. 2017, 8, 8. [CrossRef]

42. Arshad, R. Smart IoTs Based Urine Measurement System. Master's Thesis, Bournemouth University, Poole, UK, 2018.

43. Muneer, A.; Fati, S.M.; Fuddah, S. Smart health monitoring system using IoT based smart fitness mirror. TELKOMNIKA Telecommun. Comput. Electron. Control. 2020, 18, 317. [CrossRef]

44. Ando, B.; Baglio, S.; Marletta, V.; Pistorio, A.; Dibilio, V.; Mostile, G.; Nicoletti, A.; Zappia, M. A Wearable Device to Support the Pull Test for Postural Instability Assessment in Parkinson's Disease. IEEE Trans. Instrum. Meas. 2017, 67, 218-228. [CrossRef]

45. Rovini, E.; Maremmani, C.; Cavallo, F. How Wearable Sensors Can Support Parkinson's Disease Diagnosis and Treatment: A Systematic Review. Front. Neurosci. 2017, 11, 555. [CrossRef] [PubMed] 
46. Preece, J. Best Fall Detection Sensors. Available online: https://www.toptenreviews.com/best-fall-detectionsensors (accessed on 6 October 2020).

47. Laport, F.; Dapena, A.; Castro, P.M.; Vazquez-Araujo, F.J.; Iglesia, D. A Prototype of EEG System for IoT. Int. J. Neural Syst. 2020, 30, 2050018. [CrossRef] [PubMed]

48. Charara, S. This Tremor Tracking Wearable Lets Parkinson's and ET Patients Take Charge. Available online: https://www.wareable.com/health-and-wellbeing/trequant-tremor-tracking-wearable-parkinsons (accessed on 31 January 2020).

49. Nova Biomedical. StatSensorßand StatSensor Xpress ${ }^{\mathrm{TM}}$ Creatinine and eGFR Meters. Available online: https://www.novabio.us/statstrip-creatinine/ (accessed on 7 February 2020).

50. Gia, T.N.; Sarker, V.K.; Tcarenko, I.; Rahmani, A.; Westerlund, T.; Liljeberg, P.; Tenhunen, H. Energy efficient wearable sensor node for IoT-based fall detection systems. Microprocess. Microsyst. 2018, 56, 34-46. [CrossRef]

51. Majumder, A.J.A.; Elsaadany, Y.; Elsaadany, M.; Ucci, D.R.; Rahman, F. A wireless IoT system towards gait detection in stroke patients. In Proceedings of the 2017 IEEE International Conference on Pervasive Computing and Communications Workshops (PerCom Workshops), Kona, HI, USA, 13-17 March 2017; pp. 449-454.

52. Achanta, S.D.M.; Karthikeyan, T. A wireless IOT system towards gait detection technique using FSR sensor and wearable IOT devices. Int. J. Intell. Unmanned Syst. 2019, 8, 43-54. [CrossRef]

53. Campbell, E.; Gaffney, A.J.; Allen, B.E.; Robinson, C.T. LipidPlus: A Device to Monitor Lipid Profile and Blood Glucose. US Pharm 2015, 6, 23.

54. World Health Organization. Cardiovascular Diseases. Available online: https://www.who.int/health-topics/ cardiovascular-diseases/\#tab=tab_1 (accessed on 5 February 2020).

55. Johns Hopkins Medicine. Vital Signs (Body Temperature, Pulse Rate, Respiration Rate, Blood Pressure). Available online: https://www.hopkinsmedicine.org/health/conditions-and-diseases/vital-signs-bodytemperature-pulse-rate-respiration-rate-blood-pressure (accessed on 31 January 2020).

56. Cleveland Clinic. Pulse \& Heart Rate. Available online: https://my.clevelandclinic.org/health/diagnostics/ 17402-pulse--heart-rate (accessed on 31 October 2020).

57. Masimo. MightySat RRx Fingertip Pulse Oximeter. Available online: https://www.masimo.com/products/ monitors/spot-check/mightysatrx/ (accessed on 31 October 2020).

58. Masimo. MightySat@Fingertip Pulse Oximeter with Bluetooth LE, RRp, \& PVi. Available online: https://www. masimopersonalhealth.com/products/mightysat-fingertip-pulse-oximeter-with-bluetooth-le-rrp-pvi (accessed on 1 November 2020).

59. Biobeat. Medical Smart Monitoring. Available online: https://www.bio-beat.com/ (accessed on 31 October 2020).

60. Research2Guidance. How the First FDA-Cleared Cuffless Blood Pressure Solution is Paving the Way to New Remote Monitoring Technologies?-Interview with Dr. Eisenkraft, Chief Medical Officer of Biobeat. Available online: https://research2guidance.com/how-the-first-fda-cleared-cuffless-blood-pressure-solutionis-paving-the-way-to-new-remote-monitoring-technologies-interview-with-dr-eisenkraft-chief-medicalofficer-of-biobeat/\#: \{\}:text=Eisenkraft $\% 3 \mathrm{~A} \% 20$ Biobeat $\% 20$ devices $\% 20$ enables $\% 20$ cost, this $\% 20$ price $\%$ 20will\%20be\%20reduced (accessed on 1 November 2020).

61. American Heart Association. New Scientific Statement on Blood Pressure Measurement in People: American Heart Association Scientific Statement. Available online: https://newsroom.heart.org/news/new-scientificstatement-on-blood-pressure-measurement-in-people (accessed on 31 October 2020).

62. Georgiou, K.; Larentzakis, A.V.; Khamis, N.N.; Alsuhaibani, G.I.; Alaska, Y.A.; Giallafos, E.J. Can Wearable Devices Accurately Measure Heart Rate Variability? A Systematic Review. Folia Med. 2018, 60, 7-20. [CrossRef]

63. Samsung. What Does the Heart Rate Sensor Measure? Available online: https://www.samsung.com/us/ heartratesensor/ (accessed on 28 December 2019).

64. Bumgarner, J.M.; Lambert, C.T.; Hussein, A.A.; Cantillon, D.J.; Baranowski, B.; Wolski, K.; Lindsay, B.D.; Wazni, O.M.; Tarakji, K.G. Smartwatch Algorithm for Automated Detection of Atrial Fibrillation. J. Am. Coll. Cardiol. 2018, 71, 2381-2388. [CrossRef]

65. Apple. Taking an ECG with the ECG App on Apple Watch Series 4, Series 5, or Series 6. Available online: https://support.apple.com/en-us/HT208955 (accessed on 31 October 2020). 
66. January, C.T.; Wann, L.S.; Calkins, H.; Chen, L.Y.; Cigarroa, J.E.; Cleveland, J.C.; Ellinor, P.T.; Ezekowitz, M.D.; Field, M.E.; Furie, K.L.; et al. 2019 AHA/ACC/HRS Focused Update of the 2014 AHA/ACC/HRS Guideline for the Management of Patients With Atrial Fibrillation: A Report of the American College of Cardiology/American Heart Association Task Force on Clinical Practice Guidelines and the Heart Rhythm Society in Collaboration With the Society of Thoracic Surgeons. Circulation 2019, 140, e125-e151. [CrossRef]

67. AliveCor. This Is Your Heart $\times 6$. Available online: https://www.alivecor.com/kardiamobile6l/ (accessed on 31 October 2020).

68. Albert, D. A six-lead heart monitor on your smartphone: An interview with David Albert. Future Cardiol. 2020, 16, 9-11. [CrossRef]

69. AliveCor. KardiaMobile6L. Available online: https://store.alivecor.com/products/kardiamobile6l (accessed on 1 November 2020).

70. MDsave. Electrocardiogram (EKG/ECG). Available online: https://www.mdsave.com/procedures/ electrocardiogram-ekg-ecg/d182ff\#: \{\}:text=On\%20Mdsave $\% 2$ \% 20 the $\% 20$ cost $\% 20$ of,ranges $\% 20 \mathrm{from} \%$ 20\%2476\%20to\%20\%24240 (accessed on 1 November 2020).

71. Peace, K.; Wilensky, E.M.; Frangos, S.; MacMurtrie, E.; Shields, E.; Hujcs, M.; Levine, J.; Kofke, A.; Yang, W.; Le Roux, P.D. The Use of a Portable Head CT Scanner in the Intensive Care Unit. J. Neurosci. Nurs. 2010, 42, 109-116. [CrossRef] [PubMed]

72. Wang, J.C.; Bennett, M. Aging and Atherosclerosis: Mechanisms, functional consequences, and potential therapeutics for cellular senescence. Circ. Res. 2012, 111, 245-259. [CrossRef] [PubMed]

73. Da Silva, P.M.; Duarte, J.S.; Von Hafe, P.; Gil, V.; De Oliveira, J.N.; De Sousa, G. Standardization of laboratory and lipid profile evaluation: A call for action with a special focus in 2016 ESC/EAS dyslipidaemia guidelines-Full report. Atheroscler. Suppl. 2018, 31, e1-e12. [CrossRef]

74. Hall, A. The 7 Best Cholesterol Test Kits of 2020. Available online: https://www.verywellhealth.com/bestcholesterol-test-kits-4171705 (accessed on 1 November 2020).

75. International Diabetes Federation. Diabetes Facts \& Figures. Available online: https://www.idf.org/ aboutdiabetes/what-is-diabetes/facts-figures.html (accessed on 5 February 2020).

76. World Health Organization. Diabetes. Available online: https://www.who.int/news-room/fact-sheets/detail/ diabetes (accessed on 31 January 2020).

77. Healthline. New Diabetes Test Could Be More Accurate. Available online: https://www.healthline.com/ health-news/new-diabetes-test-more-accurate (accessed on 6 October 2020).

78. National Institute for Health and Care Excellence. Type 2 Diabetes in Adults: Management. Available online: https://www.nice.org.uk/guidance/ng28/chapter/1-Recommendations\#drug-treatment-2 (accessed on 5 February 2020).

79. Diabetes.co.uk. HbA1c Test Kits: Home A1c Testing Kits. Available online: https://www.diabetes.co.uk/ hba1c-meters/ (accessed on 5 February 2020).

80. Zhang, C.G.; Chang, S.J.; Settu, K.; Chen, C.-J.; Liu, J.-T. High-sensitivity glycated hemoglobin (HbA1c) aptasensor in rapid-prototyping surface plasmon resonance. Sens. Actuators B Chem. 2019, 279, 267-273. [CrossRef]

81. Diabetes.co.uk. Artificial Pancreas. Available online: https://www.diabetes.co.uk/artificial-pancreas.html (accessed on 25 September 2019).

82. Jha, V.; Garcia-Garcia, G.; Iseki, K.; Li, Z.; Naicker, S.; Plattner, B.; Saran, R.; Wang, A.Y.-M.; Yang, C.-W. Chronic kidney disease: Global dimension and perspectives. Lancet 2013, 382, 260-272. [CrossRef]

83. National Kidney Foundation. Global Facts: About Kidney Disease. Available online: https://www.kidney. org/kidneydisease/global-facts-about-kidney-disease (accessed on 6 February 2020).

84. Stevens, L.A.; Viswanathan, G.; Weiner, D.E. Chronic Kidney Disease and End-Stage Renal Disease in the Elderly Population: Current Prevalence, Future Projections, and Clinical Significance. Adv. Chronic Kidney Dis. 2010, 17, 293-301. [CrossRef]

85. De Nicola, L.; Zoccali, C. Chronic kidney disease prevalence in the general population: Heterogeneity and concerns. Nephrol. Dial. Transpl. 2016, 31, 331-335. [CrossRef]

86. Scanlon, B.K.; Levin, B.E.; Nation, D.A.; Katzen, H.L.; Guevara-Salcedo, A.; Singer, C.; Papapetropoulos, S. An accelerometry-based study of lower and upper limb tremor in Parkinson's disease. J. Clin. Neurosci. 2013, 20, 827-830. [CrossRef] 
87. Chen, T.-Z.; Xu, G.-J.; Zhou, G.-A.; Wang, J.-R.; Chan, P.; Du, Y.-F. Postural sway in idiopathic rapid eye movement sleep behavior disorder: A potential marker of prodromal Parkinson's disease. Brain Res. 2014, 1559, 26-32. [CrossRef]

88. Romero, L.E.; Chatterjee, P.; Armentano, R.L. An IoT approach for integration of computational intelligence and wearable sensors for Parkinson's disease diagnosis and monitoring. Health Technol. 2016, 6, 167-172. [CrossRef]

89. Gulia, K.K.; Kumar, V.M. Sleep disorders in the elderly: A growing challenge. Psychogeriatrics 2018, 18, 155-165. [CrossRef] [PubMed]

90. Shelgikar, A.V.; Anderson, P.F.; Stephens, M.R. Sleep Tracking, Wearable Technology, and Opportunities for Research and Clinical Care. Chest 2016, 150, 732-743. [CrossRef] [PubMed]

91. Gomes, D.; Placido, A.I.; Mó, R.; Simões, J.L.; Amaral, O.; Fernandes, I.; Lima, F.; Morgado, M.; Figueiras, A.; Herdeiro, M.T. Daily medication management and ddherence in the polymedicated elderly: A cross-sectional study in Portugal. Int. J. Environ. Res. Public Health 2020, 17, 200. [CrossRef] [PubMed]

92. Tsai, P.-H.; Chen, T.-Y.; Yu, C.-R.; Shih, C.-S.; Liu, J.W.S. Smart Medication Dispenser: Design, Architecture and Implementation. IEEE Syst. J. 2010, 5, 99-110. [CrossRef]

93. Varshney, U. Smart medication management system and multiple interventions for medication adherence. Decis. Support Syst. 2013, 55, 538-551. [CrossRef]

94. Airehrour, D.; Madanian, S.; Abraham, A.M. Designing a memory-aid and reminder system for dementia patients and older adults. In Proceedings of the 17th International Conference on INFORMATICS in ECONOMY (IE 2018), Iasi, Romania, 17-20 May 2018; pp. 75-81.

95. DLife. Advantages and Disadvantages of the Insulin Pump. Available online: https://dlife.com/advantagesand-disadvantages-of-the-insulin-pump/ (accessed on 25 September 2019).

96. Bahadori, S.; Immins, T.; Wainwright, T.W. A review of wearable motion tracking systems used in rehabilitation following hip and knee replacement. J. Rehabil. Assist. Technol. Eng. 2018, 5, 1-8. [CrossRef]

97. Antón, D.; Nelson, M.; Russell, T.; Goñi, A.; Illarramendi, A. Validation of a Kinect-based telerehabilitation system with total hip replacement patients. J. Telemed. Telecare 2015, 22, 192-197. [CrossRef]

98. Grant, S.; Blom, A.W.; Whitehouse, M.R.; Craddock, I.; Judge, A.; Tonkin, E.L.; Gooberman-Hill, R. Using home sensing technology to assess outcome and recovery after hip and knee replacement in the UK: The HEmiSPHERE study protocol. BMJ Open 2018, 8, e021862. [CrossRef]

99. Eichler, S.; Rabe, S.; Salzwedel, A.; Mueller, S.; Stoll, J.; Tilgner, N.; John, M.; Wegscheider, K.; Mayer, F.; Völler, H. Effectiveness of an interactive telerehabilitation system with home-based exercise training in patients after total hip or knee replacement: Study protocol for a multicenter, superiority, no-blinded randomized controlled trial. Trials 2017, 18, 438. [CrossRef]

100. Chen, Y.; Abel, K.T.; Janecek, J.T.; Chen, Y.; Zheng, K.; Cramer, S.C. Home-based technologies for stroke rehabilitation: A systematic review. Int. J. Med. Inform. 2019, 123, 11-22. [CrossRef]

101. Ortiz-Piña, M.; Salas-Fariña, Z.; Mora-Traverso, M.; Martín-Martín, L.; Galiano-Castillo, N.; García-Montes, I.; Cantarero-Villanueva, I.; Fernández-Lao, C.; Arroyo-Morales, M.; Mesa-Ruiz, A.; et al. A home-based tele-rehabilitation protocol for patients with hip fracture called @ctivehip. Res. Nurs. Heal. 2018, 42, 29-38. [CrossRef] [PubMed]

102. Cottrell, M.A.; Galea, O.A.; O'Leary, S.P.; Hill, A.J.; Russell, T.G. Real-time telerehabilitation for the treatment of musculoskeletal conditions is effective and comparable to standard practice: A systematic review and meta-analysis. Clin. Rehabil. 2016, 31, 625-638. [CrossRef] [PubMed]

103. Alaba, F.A.; Othman, M.; Hashem, I.A.T.; Alotaibi, F. Internet of Things security: A survey. J. Netw. Comput. Appl. 2017, 88, 10-28. [CrossRef]

104. Jaleel, A.; Mahmood, T.; Hassan, M.A.; Bano, G.; Khurshid, S.K. Towards Medical Data Interoperability Through Collaboration of Healthcare Devices. IEEE Access 2020, 8, 132302-132319. [CrossRef]

105. Conti, M.; Dehghantanha, A.; Franke, K.; Watson, S. Internet of Things security and forensics: Challenges and opportunities. Future Gener. Comput. Syst. 2018, 78, 544-546. [CrossRef]

106. Mahmoud, R.; Yousuf, T.; Aloul, F.; Zualkernan, I. Internet of things (IoT) security: Current status, challenges and prospective measures. In Proceedings of the 2015 10th International Conference for Internet Technology and Secured Transactions (ICITST), London, UK, 14-16 December 2015; pp. 336-341.

107. Alkhatib, S.; Waycott, J.; Buchanan, G.; Bosua, R. Privacy and the Internet of Things (IoT) Monitoring Solutions for Older Adults: A Review. Stud. Heal. Technol. Inform. 2018, 252, 8-14. 
108. Hussain, I. Internet of Things: Challenges and research opportunities. CSI Trans. ICT 2017, 5, 87-95. [CrossRef]

109. Kiourtis, A.; Mavrogiorgou, A.; Menychtas, A.; Maglogiannis, I.; Kyriazis, D. Structurally Mapping Healthcare Data to HL7 FHIR through Ontology Alignment. J. Med. Syst. 2019, 43, 62. [CrossRef]

110. Lamprinakos, G.; Mousas, A.; Boufis, A.; Karmiris, P.; Mantzouratos, S.; Kapsalis, A.; Kaklamani, D.; Venieris, I. Using FHIR to develop a healthcare mobile application. In Proceedings of the 4 th International Conference on Wireless Mobile Communication and Healthcare- "Transforming healthcare through innovations in mobile and wireless technologies", Athens, Greece, 3-5 November 2014; pp. 132-135.

111. HL7 FHIR. FHIR Overview. Available online: https://www.hl7.org/fhir/overview.html (accessed on 4 October 2019).

Publisher's Note: MDPI stays neutral with regard to jurisdictional claims in published maps and institutional affiliations.

(C) 2020 by the authors. Licensee MDPI, Basel, Switzerland. This article is an open access article distributed under the terms and conditions of the Creative Commons Attribution (CC BY) license (http://creativecommons.org/licenses/by/4.0/). 